\title{
MAQASID SHARI'AH SEBAGAI PENDEKATAN SISTEM DALAM HUKUM ISLAM
}

\author{
Nasrulloh \\ Pascasarjana IAIN Sunan Ampel Surabaya \\ Email: Nasrulloh.said@gmail.com
}

\begin{abstract}
Abstrak
Figh is not God's regulation that must be obeyed because it is faqih's (the expert of figh) understanding on Qur'an and Sunnah. Therefore, this understanding product may be different one another since it has the possibility to be valid or invalid as human's thinking. Jaseer offers Maqasid Shari'ah as a systematical approach in Islamic law to get valid figh product based on universal meaning of these two Islamic doctrine sources. In this writing, there are five concepts contributing by Jasser to formulate and to understand shariah to be figh product namely validating all-cognition, holism, openness and self-renewal, multi-dimensionality dan purposefulness.

Figh bukanlah aturan Tuhan yang mesti harus ditaati, karena figh hanyalah hasil produk seorang faqih dalam memahami al-Qur'an dan al-Sunnah, maka hasil produk satu faqih dengan yang lainnya pastilah berbeda, karena ia sekali lagi adalah hasil pemikiran manusia yang bisa mempunyai kemungkinan benar dan salah. Jaseer menawarkan Maqasid Shari'ah Sebagai Pendekatan Sistem Dalam Hukum Islam, guna mencapai produk figh yang benar-benar sesuai dengan makna universal yang dikandung oleh al-Qur'an dan al-sunnah. Dalam tulisan ini, ada lima konsep yang disumbangkan oleh Jaseer untuk mengolah dan memahami Shari'ah sebelum ia menjadi produk figh, yaitu validating all-cognition, holism, openness and self-renewal, multidimensionality dan purposefulness.
\end{abstract}

Kata Kunci: Fiqh, Maqasid Shari'ah, pendekatan sistem

Fiqh sering kali oleh sebagian kelompok dianggap sebagai hukum Tuhan yang memiliki otoritas penuh, sehingga dengan sendirinya ia menjadi sakral. Hal ini tanpa disadari menyebabkan kejumudan ijtihad yang merupakan bagian penting dalam hukum Islam. Sehingga wajar, apabila muncul paradigma pintu ijtihad telah ditutup. Dengan begitu Islam menjadi agama yang kaku, konservatif dan tidak membuka diri terhadap kemajuan perkembangan zaman yang tidak mungkin bisa terbendung lagi, Islam menjadi agama yang ke Arab-araban, hasil dari penafsiran tekstualis agama yang memang saat itu turun di wilayah Arab dan Islam hanya akan menjadi agama yang cocok bagi orang Arab. Jika hal ini dibiarkan terus menerus, maka prinsip utama Islam yaitu sebagai agama yang rahmatan lil 'alamin idak bisa terwujud. Kenyataan inilah yang mendorong Jaseer Audah untuk memahami Islam secara substansinya dengan menggagas konsep Maqasid Al-Shariah sebagai system pendekatan dalam memahami hukum Islam, agar dapat jalan sesuai dengan prinsip utamanya, sehingga hukum Islam selalu relevan kapanpun, dimanapun dan untuk siapapun.

Hal yang harus diperhatikan adalah perlu dibedakan antara wahyu Tuhan - yang pertama adalah al-Qur'an yang tidak bisa diganggu gugat kebenarannya dan kedua adalah hadis yang mana masih banyak menyisakan persoalan keotentikannya - dengan penafsiran terhadap wahyu Tuhan, perlu dibedakan antara Kehendak Tuhan yang ideal dengan pemahaman manusia yang terbatas, sehingga tidak ada otoritarianisme dalam hukum 
dan pengkafiran terhadap sesama muslim. Yang pasti, fiqh adalah hasil produk pemikiran manusia sesuai dengan world view yang dimiliki. Maka, tidak heran bila produk fiqh yang dihasilkan selalu tidak pernah disepakati oleh seluruh umat, dari mulai generasi sahabat sampai sekarang.

Menurut Jaseer, Sebenarnya, ada perbedaan antara shari'ah dengan fiqh dan dengan fatwa, shari'ah adalah wahyu yang diterima Nabi melalui malaikat Jibril as, sedangkan penerapan dan aplikasi adalah tujuan dan risalah yang ingin diterapkan kepada ummat seluruh manusia, secara sedarhana ia adalah al-Qur'an dan sunnah. Sedangkan figh adalah beragam kumpulan pendapat-pendapat fuqaha' atas pemahaman mereka sendirisendiri yang didasarkan pada al-Qur'an dan sunnah, dengan menggunakan pendekatan dan metode yang berbeda-beda, di berbagai sisi kehidupan sepanjang sejarah Islam yang sudah lebih dari 14 abad. Sedangkan fatwa adalah penerapan shari'ah dengan fiqh pada kehidupan ummat hari ini yang selalu up to date. ${ }^{1} \mathrm{Hal}$ ini memberikan pamahaman kepada kita bahwasannya tidak ada pendapat fiqh yang benar-benar bisa diyakini kebenarannya secara mutlak tanpa memperhatikan keautentikan (thubut), dilalah, ijma' dan qiyas.

\section{Menuju Validitas Pengetahuan ( Idrak)}

Jaseer Audah dalam bukunya Maqasid As Philoshophy Of Islamic Law dengan tegas mengkritisi sabagian ahli hukum yang menggambarkan bahwa hukum fiqh sebagai aturan Tuhan yang mesti harus ditaati. Mereka mengklaim bahwa pendapat-pendapat mereka yang dihasilkan dari pemahaman dan persepsi adalah perintah Tuhan, walaupun pendapat mereka-menurut Jaseersangat mungkin bisa keliru dan disalah gunakan oleh sebagian kelompok atau untuk kepentingan tertentu. ${ }^{2}$

\footnotetext{
'Jaseer Audah, Maqasid al- Shari'ah Falsafah Li al-Tashrii al-Islami (London: The International Institute Of Islamic Thought, 2007), h. 8.

2Jaseer Audah, Maqasid As Philoshophy Of Islamic Law (London: The International Institute Of Islamic Thought, 2008), h. 193.
}

Jaseer juga mengatakan bahwa hasil ijma' sering kali dikatakan atau diklaim sebagai 'revealed knowledge', meski setiap mujtahid mempunyai metode atau pendekatan yang berbeda dengan pendekatan mujtahid lainnya, maka dari itu, ijma' bukanlah hasil mutlak yang bisa diyakini kebenarannya secara pasti. Bahkan Jaseer sangat menyesalkan sebagian ahli hukum yang mengkafirkan kelompok yang tidak mengakui hasil ijma'. ${ }^{3}$ Para ahli fiqh sadar betul bahwa hasil ijma' antara satu ulama' dengan ulama' lainnya. Sebagai contoh, Ibnu Taymiyah mengkritisi hasil ijma' yang ditulis olehh Ibn Hazm dalam bukunya Maratib Al-Ijma, hasil kritikan Ibnu Taymiyah ini kemudian dibukukan sendiri oleh beliau dalam sebuah buku yang berjudul Naqd Maratib Al-Ijma'. Ibnu Taymiyah menyebutkan banyak contoh yang dikutib oleh Ibnu Hazm yang tidak sesuai dengan hasil ijma', salah satu contohnya adalah para ahli hukum menghukumi kafir orangorang yang menolak hasil ijma', perempuan dilarang menjadi pemimpin dan menjadi imam shalat. ${ }^{4}$

Jaseer menegaskan bahwa ijma' bukanlah sumber hukum dalam islam, ia hanyalah sebuah media untuk mencari kebenaran saja, dan bukanlah kebenaran itu sendiri, karena kenyataannya, hasil ijma' sering diselewengkan untuk kepentingan tertentu. Jaseer lebih setuju dengan pendapat ulama' modern yang menganggap ijma' hanya sebagai media untuk mengumpulkan fatwa, terlebih lagi di era teknologi dan komunikasi. Bahkan Jaseer sangat setuju lagi, bila semua masyarakat tanpa kecuali dilibatkan dan diberi peluang untuk menyampaikan aspirasinya mengenai hukum islam. ${ }^{5}$

\section{Menuju Totaliterism (Holism)}

Menurut Jaseer, sekarang ini penerapan produk figh (penerapan yang buruk) selalu ikhtizaliyyan bukannya shumuliyyan, harfiyyan bukannya akhlaqiyyan, ahadiy al-bu'di bu-

\footnotetext{
${ }^{3}$ Jalal Al-Din Al-Suyuti, Al-Dur Al-Manthur Jilid 3 (Bairut: Dar Al-Fikr, 1993), h. 86.

${ }^{4}$ Ibnu Taymiyah, Naqd Maratib Al-Ijma' (Bairut; Dar AlFikr, 1993), h. 75.

${ }^{5}$ Jaseer Audah, Maqasid..., h. 194,
} 
kannya ahadiy al-ab'ad . Sedikit ahli hukum yang memperhatikan batasan dari pendekatan reduksi dan atomism yang mana metode ini biasa digunakan oleh kelompok fundamental. Fakhr Al-Din Al-Razi meringkas beberapa perbedaan alasan para ahli hukum tentang kenapa dalil al-khitab dari sebuah teks hanya bersifat zanni. Berikut ini adalah ringkasan alasan-alasan tersebut; ${ }^{7}$ 1) Ada kemungkinan dari hukum yang kita hasilkan dari sebuah teks tunggal sudah dibatasi oleh suatu keadaan tertentu, sedangkan kita tidak mengetahuinya, 2) Ada kemungkinan bahwa ungkapan dari teks tunggal tersebut mempunyai makna majaz, 3) Refrensi bahasa kita adalah dari ahli bahasa, yang mana setiap orang mempunyai kemungkinan untuk salah. 4) Gramatika bahasa arab disampaikan kepada kita melalui syair-syair arab kuno dengan jalur riwayat ahad. Dan semua itu tidak bisa diyakini valid, karena para penyair tersebut bisa saja salah, 5) Sangat dimungkinkan satu kata atau lebih dari sebuah teks mempunyai banyak makna atau tafsir, 6) Ada kemungkinan satu kata atau lebih dari sebuah teks maknanya sudah dirubah, dan pada waktu selanjutnya yang merubah adalah makna awal yang dirubah tadi, 7) Ada kemungkinan terdapat makna tersembunyi dari sebuah ungkapan yang kita tidak faham, 8) Boleh jadi hukum yang kita pertimbangkan dari sebuah teks tunggal sudah di mansukh tanpa sepengetahuan kita, 9) Boleh jadi hukum yang kita pertimbangkan dari sebuah teks tunggal berlawanan dengan logika kebenaran. Sebagaimana yang disampaikan oleh al-Razi, jika kedua hasil hukum tadi dan hadis kita gabungkan, maka terdapat kesalahan salah satunya.

Selain dari pada itu, akal adalah sarana kita untuk memastikan keabsahan dari sebuah hadis itu sendiri. Oleh karena itu akal memiliki kedudukan lebih tinggi daripada hadis, karena tanpa akal, nas tidak dapat difahami, dan sepatutnya kita mengikuti akal kita untuk menentukan kebenaran pada tiap

\footnotetext{
$\overline{{ }^{6}}$ Jaseer Audah, Maqasid..., h. 11,

${ }^{7}$ Muhammad Ibn 'Umar al-Razi, al-Mahsul, ed Taha Jabir al-Alwani (Riyadh; Imam Muhammad University Press, 1400 H), h. 547-573.
}

kasus, bukannya mengikuti dalil ilmu kebahasaan dari sebuah teks. Di sini Jaseer ingin menambahi tiga poin dari sembilan poin diatas; 1) Ada kemungkinan sebuah teks mempunyai makna yang bertentangan dengan teks lainnya, teks semacam ini biasa dikenal dengan istilah al-nusus al-muta'aridah. 2) Ada jarak yang sangat memungkinkan terjadinya kesalahan dalam penyampaian hadis ahad, yang mana hadis Nabi sangat banyak yang diriwayatkan secara ahad. 3) Ada jarak yang sangat memungkinkan terjadinya interpretasi dari setiap teks tunggal, yang mana hal ini mempengaruhi cara pandang kita dalam memahami makna atau maksud dari sebuah hadis. ${ }^{8}$

Dari paparan diatas, seorang faqih perlu kiranya memperluas pandangannya dan memperdalam keluasan ilmu, sebelum mengeluarkan fatwa yang sangat berpengaruh pada masyarakat. Maka dari itu, seorang faqih tidak bisa membuat produk hukum hanya dengan bersandar pada satu dalil baik dari alQur'an maupun hadis untuk dibuat hujjah.

\section{Menuju Keterbukaan Dan Pembaharuan}

Sebuah sistem bisa tetap eksis manakala tetap menjaga atau mempertahankan openness and self-renewal. Jaseer menawarkan dua mekanisme dalam hukum Islam agar openness and self-renewal bisa terwujud. Pertama, berubahnya sebuah hukum seiring dengan berubahnya cara pandang para ahli kukum atau pengetahuannya tentang budaya. Kedua, philosophy keterbukaan menawarkan diri sebagai mekanisme dari self-renewal dalam hukum islam.

Worldview adalah sebuah istilah yang sudah dikenal sejak seratus tahun yang lalu dengan nama 'world outlook'. ${ }^{9}$ Worldview adalah hasil atau produk dari sekian jumlah faktor yang dapat membentuk seseorang memiliki pengetahuan yang luas atau 'human cognition of the world'. Worldview dihasilkan dari segala sesuatu yang mengelilingi kita atau yang ada di sekitar kita, seperti agama, lingkungan, politik, masyarakat, ekonomi, bahasa dsb.

\footnotetext{
${ }_{8}^{8}$ Jaseer Audah, Maqasid..., h. 198.

'David K. Naugle, Worldview; The History of Concept (Grand Rapids: Eerdmans, 2002), h. 2.
} 
Berdasarkan tradisi, dasar atau asas dari al-'urf dalam teori hukum Islam, sama halnya berinteraksi dengan dunia luar (interaction with the outside world). Dalam kaidah yang diusung oleh Hanafiyyah menegaskan bahwa al-ma'rufu 'urfan ka al-mashruti shartan. Kaidah ini telah disepakati oleh berbagai macam sekolah hukum untuk bisa diterapkan di berbagai ranah masalah yang berkaitan dengan hukum, selama tidak ada nas yang menyinggung hal tersebut. Sebagai contoh standar dalam hal ini, sebagaimana yang dikenalkan oleh buku-buku usul dalam hukum islam adalah, nilai mahar wanita, penggunaan mata uang di setiap Negara, mengenakan penutup kepala atau tidak mengenakannya, penggunaan secara umum beberapa kalimat berbahasa arab dan sebagainya. ${ }^{10}$ Tujuan dibalik melibatkan 'urf dalam menentukan hukum Islam adalah untuk mengakomodasi atau menampung berbagai macam keadaan orang yang berbeda dengan tradisi orang arab, yang mana seluruh syariat pada awalnya diturunkan dan ditujukan untuk mereka pada waktu itu. Tetapi kenyatannya, implikasi praktis (al-athar al'amaliyyah) dari al-'urf dalam kajian fiqh telah benar-benar dibatasi.

Banyak dari para fuqaha' yang masih melihat dan berkiblat pada tradisi-tradisi arab pada abad pertama, kedua dan ketiga sebagai acuan dalam menentukan hukum Islam. Contohnya dalam hal bentuk pakaian dan sadaqah fitri masih ditetapkan menggunakan bahan makanan pokok secara umum pada zaman abad dulu, seperti kurma, kismis dan gandum, bahkan dalam ranah politik masih berkiblat pada zaman dulu, seperti istilah 'the land of islam' dan 'the land of war'. ${ }^{11}$ Berdasarkan fatwa hukum islam yang dikeluarkan oleh salah satu fuqaha'; seorang gadis tidak dapat menikah kecuali jika dia mewakili ayahnya atau kerabat laki-lakinya yang terdekat untuk menyampaikan aqad nikah untuk kepentingannya, hal ini sesuai dengan tradisi orang arab. Sebagaima-

\footnotetext{
${ }^{10}$ Masoud Ibnu Musa Flousi, Madrasah al-Mutakallimin (Riyadh: Maktabah al-Rush, 2004), h. 354.

${ }^{11} \mathrm{Ibnu}$ al-Qayyim, Ahkam Ahl al-Dhimmah Jilid 2 (Riyadh: Ramadi, 1997), h. 728.
}

na yang diungkapkan oleh Ibnu Taymiyah, Ahl al-Sunnah meyakini bahwa ras arab lebih unggul daripada selainnya, ia kemudian mendiskripsikan orang-orang yang tidak meyakini pendapat ini sebagai orang yang nasionalis atau shu'ubiyyun. ${ }^{12}$ Pendapat ini, menurut Jaseer masih masih banyak yang meyakini kebenarannya, padahal di berbagai ayat al-Qur'an dan literatur hadis tidak dijumpai salah satu ras lebih baik dari ras lainnya. Ibnu Taymiyah juga menolak orang non arab memimpin orang arab dalam suatu pemerintahan, bahkan non arab tidak boleh menjadi imam dari orang arab, tidak boleh orang non arab yang tidak kufu menikahi wanita arab, dan sebagainya. ${ }^{13}$ Semua contoh tersebut memberikan gambaran secara jelas kepada kita bahwasannya ada kontradiksi antara maqasid shari'ah tentang persamaan derajat manusia yang di sebutkan oleh nas dengan fatwa-fatwa diatas. Dari paparan diatas, jelaslah bahwasannya al-'urf adalah sesuatu yang dipandang 'urf oleh fuqaha' berdasarkan kemampuan keilmuan dan pengetahuan mereka, selama tidak bertentangan dengan maqasid shari'ah. Oleh karena itu, cara pandang 'worldview' sangat diperlukan bagi fuqaha' untuk memperluas metode yang menggunakan al'urf sebagai upaya untuk mengakomodir perubahan-perubahan budaya dunia yang tentunya berbeda dengan budaya arab, sehingga menghasilkan produk fiqh yang benar-benar bisa dipertanggung jawabkan. ${ }^{14}$

\section{Menuju Multidimensionalitas}

Kepastian (al-qat') dan ketidak pastian (alzann) adalah dua istilah yang sering mendominasi dalam berbagai metodologi dan kajian di berbagai pendidikan hukum islam. Al-Ghazali mendefinisikan ilmu kalam sendiri sebagai hukum yang bisa dibuat untuk mengidentifikasi sebuah definisi, analogi dan membedakan pengetahuan atau ilmu

\footnotetext{
${ }^{12}$ Ahmad Ibnu Taymiyah, Iqtida' al-Srat al-Mustaqim Mukhalafah Ashab al-Jahim (Cairo: Matba'ah al-Sunnah, $1369 \mathrm{H})$, h. 148-150.

${ }^{13} \mathrm{Ibnu}$ Rushd, Bidayah alMujtahid Wa Nihayah al-Muqtasd Jilid 2 (Bairut: Dar Al-Fikr, 1985), h. 12.

${ }^{14}$ Jaseer Audah, Maqasid., h. 203.
} 
al-yaqini dari ilmu lainnya. ${ }^{15}$ Beberapa dalil pokok yang dilegitimasi untuk tujuan inti adalah memperluas wilayah al-qat' dalam hukum islam. Sebagai contoh misalnya, Ali Jumah berargumen tentang pentingnya ijma', karena terbatasnya perangkat-perangkat pokok yang digunakan untuk memahami implikasi nass dalam area kepastian hukum, dan ijma' akan dapat memperluas area kepastian dan mengubah implikasi-implikasi zanni kepada wilayah qat'i. ${ }^{16}$

Diantara instruksi al-Qur'an dan hadis yang diklaim secara qat'i ditinjau dari segi implikasi bahasa misalkan didapati dari contoh hadis-hadis Nabi berikut ini; 1) Nabi mendengar ada dua orang yang berselisih tentang persewaan kebun, lalu kemudian beliau bersabda;" jika seperti ini tabiat kalian, maka janganlah menyewakan kebun"17 2) Seorang perempuan bertanya kepada Nabi ; "Anakku inilah yang aku gendong di perutku, aku susui dari susuku dan ia tidur di pangkuanku. Ayahnya menceraikanku, dan sekarang ia mau mengambilnya dariku, bagaimana ini ya Rasul?" Kemudian Nabi menjawab; "Anakmu masih tetap dalam dekapanmu selama kamu belum menikah". ${ }^{18} 3$ ) Nabi pernah bersabda; "Seorang muslim tidak perlu membayat zakat atas kuda-kuda yang dimilikinya". 4) Nabi bersabda; "tebusan atas pembunuhan manusia adalah 100 unta"19.

Dengan pemahaman yang mengedepankan makna tekstual, maka hadis-hadis diatas mempunyai makna; 1) Dilarang menyewakan ladang. ${ }^{20}$ 2) Hak asuh anak menjadi kewenangan Ibu selama belum menikah lagi. ${ }^{21}$ 3) Tidak ada zakat bagi kuda ${ }^{22}$ 4) Tebu-

\footnotetext{
${ }_{15}$ Abu Hamid Abu Hamid al-Ghazali, Maqasid al-Falsafiyyah (Cairo: Dar al-Ma'rifah, 1961), h. 3.

16 Ali Jumaa, Usul al-Figh wa 'alaqatuhu bi al-Falsafah al-Islamiyah (Cairo: Al-Ma;had al-'Alami li Al-Fikr alIslami, 1996), h. 29.

${ }^{17}$ Sulayman Abu Dawud, Sunan Abu Dawud Jilid 3 (Damascus; Dar Al-Fikr), h. 257.

${ }^{18}$ Al-Hakim al-Naysaburi, Al-Mustadrak Jilid 2 (Dar alKutub al-'Ilmiyyah, 1990), h. 255.

${ }^{19}$ Al-Bukhari, Sahih Al-Bukhari Jilid 5 (Bairut: Dar Ibni Kathir, 1407 H), h. 2216.

${ }^{20}$ Al-Bukhari, Sahih., h. 532

${ }^{21}$ Ibnu Rushd, Bidayah., h. 43.

${ }^{22}$ Jaseer Audah, Maqasid., h. 213.
}

san atas pembunuhan adalah 100 unta. $^{23}$

Metode untuk menyarikan hukum-hukum dari nass-nass yang jelas dan pasti haruslah mempertimbangkan dalil-dalil lain yang mungkin dapat memalingkan dari makna wajib menjadi makna yang tidak wajib. Tetapi yang memalingkan nass dari makna wajib ke makna yang lain haruslah setingkat derajatnya. Kalau tidak, maka ia tetap dalam makna wajib, sesuai dengan asasnya yaitu al amru yufidu al-wujub karena nass itu berasal dari Allah dan Rasulnya maka dalil yang dapat memalingkan dari makna asalnya haruslah dari Allah dan Rasulnya juga. Misalnya kita dapat mengandaikan penafsiran perintah Nabi itu mengandung kemungkinan; ia tidak dimaksudkan untuk sesuatu yang pasti, tapi ditujukan untuk konsteks tertentu yang melatar belakangi perintah Nabi tersebut, seperti faktor ekonomi, politik dan sosial. Dalam contoh-contoh hadis diatas, penafsirannya bisa mengandung kemungkinan seperti berikut; 1) Nabi melarang sahabat untuk menyewakan ladang hanya karena adanya pertikaian di antara mereka, karena perintah ini berlaku hanya ketika ada kemungkinan untuk pertikaian. Dengan kata lain, jika tidak ada pertikaian antara kedua belah pihak, maka diperbolehkan sewa ladang. 2) Nabi mengetahui bahwasannya hak perwalian anak model seperti ini sesuai untuk kondisi social tertentu saja, dan pada waktu itu. Dan Nabi tidak memaksudkan perintah itu berlaku umum. 3) Jika kuda-kuda itu telah mencapai jumlah yang cukup, maka zakat akan berlaku padanya. 4) Fidyah berupa uang atau 100 unta itu bergantung pada kebudayaan arab yang dominan.

Madzhab fiqh klasik tidak menyetujui satupun dari empat bentuk argumentasi diatas, kecuali penafsiran yang pertama, karena ada dalil otentik yang sama yang menunjukkan bahwasannya Nabi menyetujui penyewaan ladang bagi sahabat yang lain. ${ }^{24}$

\section{Menuju 'Purposefulness'}

Untuk menjelaskan maksud dari poin di atas, contoh-contoh berikut ini yang ${ }^{23}$ Ibnu Hajar, Fath al-Bari, jil 10, h. 375.

24 'Ali al-'Amidi, Al-Ihkam fi Usuli al-Ahkam Jilid 4 (Bairut: Dar al-Kitab al-'Arabi, 1404 H), h. 249. 
disampaikan oleh Ibnu 'Ashur memberikan gambaran kepada kita, tentang bagaimana mangambil sebuah kesimpulan atau mengambil sebuah hukum dan memahami maksud dari hadis-hadis Nabi. Melalui cara pandang maqasid al-shari'ah yang terkandung dalam hadis-hadis beliau, kita akan menghasilkan sebuah produk hukum yang bisa diyakini lebih mendekati kepada kebenaran, dalam setiap hadis yang ada, tidaklah semuanya mempunyai makna tashri', tetapi mempunyai dua belas makna yang berbeda; ${ }^{25}$

Pertama; untuk tujuan tashri'; seperti ucapan Nabi pada saat haji wada'خذوا عني مناسكرuucapan Nabi seperti ini wajib diikuti sebagaimana mestinya. Dari hadis terebut, seakan-akan Nabi bersabda; perhatikanlah semua perbuatan yang Aku kerjakan dan ikutilah. Maka, semua perbuatan-perbuatan Nabi tersebut bersifat wajib.

Kedua; untuk tujuan fatwa; sebagaimana ucapan Nabi juga ketika haji wada', seseorang datang kepada Nabi lalu bertanya; "ya Nabi, saya telah memotong hewan, sebelum melempar jumrah" Nabi menjawab; "tidak apa-apa". Kemudian ada lagi seseorang yang bertanya kepada beliau lagi; "ya Nabi, saya telah mencukur rambut sebelum menyembelih hewan" Nabi menjawab; “tidak apa-apa". Seorang perawi ketika mengamati hadis-hadis Nabi, menemukan bahwa Nabi tidaklah ditanya seseorang tentang apakah ini didahulukan atau diakhirkan, kecuali mengatakan; "lakukanlah, tidak apa-apa". Dari beragam hadis Nabi mengenai fatwa -fatwa Nabi diatas, seorang mufti, akan belajar dan memahami bahwasannya tertib dalam beribadah haji tidaklah wajib, kecuali ada yang sarih.

Ketiga; untuk tujuan memberikan keputusan bagi kedua belah pihak yang bertikai; seperti keputusan Nabi terhadap dua orang yang satu dari hadramaut dan yang satu dari kindah mengenai masalah tanah. Keputusan Nabi terhadap Habibah dan Thabit. Ha-

\footnotetext{
${ }^{25}$ Muhammad al-Tahir ibn 'Ashur, Ibnu 'Ashur Treatise on Maqasid al-Shari'ah, terj. Muhammad al-Tahir al-Musawi (London: International Institute of Islamic Thought, 2006), h. 24.
}

bibah mengadu kepada Nabi, sesungguhnya ia tidak mencintai suaminya dan ingin berpisah darinya, kemudian Nabi bertanya kepada habibah; "apakah kamu mau mengembalikan kebunnya (maharnya)?" Habibah menjawab; "ya, sedikit sekali yang ia berikan kepadaku", setelah itu Nabi menceraikan keduanya dengan catatan, Habibah mengembalikan mahar yang telah diberikan kepadanya. Kasus seperti ini menurut Ibnu 'Ashur, tidak bisa dikatakan sebagai tashri' 'am, melainkan Nabi memberikan keputusan tersebut sesuai dengan kemaslahatan kedua belah pihak tadi, yaitu Habibah dan Thabit.

Keempat; untuk tujuan imarah (posisi Nabi sebagai hakim bagi kaum muslimin). Seperti hadis Nabi tentang diperbolehkannya seseorang memiliki tanah yang kosong, asalkan ia mau merawatnya, larangan Nabi untuk makan keledai kampong pada perang khaibar. Maka, kaidah secara universal mengatakan, bahwa setiap hadis Nabi yang bersentuhan dengan urusan sosial masyarakat dan politik, maka harus difahami maksud di balik pernyataan Nabi tersebut, demi tujuan maslahah yang menyeluruh.

Kelima; untuk tujuan al-irshad (mempunyai makna lebih luas daripada makna tashri'). Seperti hadis dalam Sahih al-Bukhari, disebutkan bahwasannya, Abu Dzar telah menghina Ibu dari budak yang dimilikinya, lalu budak tersebut mengadu kepada Nabi, setelah itu Nabi berkata kepada Abu Dzar; "sesungguhnya dalam dirimu masih ada karakter jahiliyyah, budakmu adalah saudaramu", dari hadis ini, seorang faqih menemukan petunjuk Nabi tentang cara berinteraksi dengan budak.

Keenam; untuk tujuan musalahah; seperti dalam kasus Barirah, Nabi meminta kepadanya untuk ruju' kepada suaminya yang telah menceraikannya, lalu Barirah bertanya kepada Nabi ; "apakah engkau menyuruhku ya Nabi ?" Nabi menjawab; "tidak, aku hanya ingin membantumu dari masalah ini", lalu Barirah mengatakan; "kalau begitu, aku tidak mau kembali kepada suamiku". Untuk tujuan isharah kepada al-mustashir; se- 
perti sebuah riwayat, bahwasannya Umar ibn al-Khattab ingin membeli kuda dari seseorang yang ingin memberikan kuda tersebut kepadanya, karena dikira akan diberikan dengan harga murah, lalu Umar menyampaikan perihal keinginannya tersebut kepada Nabi, lalu beliau mengatakan; "jangan kau beli kuda tersebut, meskipun harganya satu dirham, karena sesungguhnya orang yang menarik kembali shadaqahnya seperti anjing yang memakan kembali makanan yang telah dimuntahkannya". Para sahabat Nabi tidak ada yang menganggap tentang larangan ini sebagai larangan yang bersifat umum, seperti hadis yang diriwayatkan oleh zaid, Nabi bersabda; "jangan lakukan akad jual beli pada buah yang belum bias dipastikan ranumnya", hadis ini difahami oleh zaid sebagai hadis isharah kepada al-mustashir. ${ }^{26}$

Ketujuh; untuk tujuan isharah kepada almustashir; seperti sebuah riwayat, bahwasannya Umar ibn al-Khattab ingin membeli kuda dari seseorang yang ingin memberikan kuda tersebut kepadanya, karena dikira akan diberikan dengan harga murah, lalu umar menyampaikan perihal keinginannya tersebut kepada Nabi, lalu beliau mengatakan; "jangan kau beli kuda tersebut, meskipun harganya satu dirham, karena sesungguhnya orang yang menarik kembali shadaqahnya seperti anjing yang memakan kembali makanan yang telah dimuntahkannya". Para sahabat Nabi tidak ada yang menganggap tentang larangan ini sebagai larangan yang bersifat umum, seperti hadis yang diriwayatkan oleh zaid, Nabi bersabda; "jangan lakukan akad jual beli pada buah yang belum bisa dipastikan ranumnya", hadis ini difahami oleh zaid sebagai hadis isharah kepada almustashir. ${ }^{27}$

Kedelapan; untuk tujuan nasihat; seperti hadis yang diceritakan oleh Al-Nu'man Ibn Bashir, sesungguhnya ayahnya bercerita kepada Nabi, sesungguhnya ia telah memberikan hadiah kepada salah satu anaknya, lalu

\footnotetext{
${ }^{26}$ Al-Bukhari, Sahih Al-Bukhari Jilid 2 (Bairut: Dar Ibni Kathir, 1407 H), h. 762.

${ }^{27}$ Al-Bukhari, Sahih Al-Bukhary ( Bairut; Dar Ibni Kathir,1407 H), jil 2, 762
}

Nabi bertanya; "apakah semua anakmu juga kamu beri hadiah itu?" ia menjawab; "tidak", kemudian Nabi bersabda; "jangan Malik kau tampakkan kedzaliman ini kepadaku". Dari hadis ini, baik Imam, Imam Abu Hanifah maupun Imam Shafi'i tidak mengharamkan hadiah yang telah diberikan oleh ayahnya al-N u'man kepada salah satu anaknya, juga tidak megharamkan pemberian itu sendiri.

Kesembilan; untuk tujuan penyempurnaan keadaan jiwa atau hati; hadis-hadis semacam ini banyak sekali, yang tidak ditujukan kepada semua ummatnya. Dalam hadis riwayat al-bukhari dari Al-Barra' Ibn 'Azib Nabi bersabda; "kami diperintahkan untuk melakukan perkara tujuh dan meninggalkan perkara tujuh; kami diperintahkan untuk menjenguk orang sakit, mengiringi jenazah, menjawab orang yang bersin, melaksanakan sumpah, menolong orang, menebarkan salam, memenuhi panggilan undangan. Nabi melarang untuk memakai cincin emas, menggunakan wadah dar perak, memakai sutra tebal, sutera tipis, memakai pakaian khas mesir yang pinggirnya diberi hiasan sutera " di antara semua perkara di atas, ada yang harus atau wajib diketahui dan ada juga yang tidak, hanya untuk sebagian sahabat saja, guna untuk mensucikan jiwa para sahabat dari sifat yang buruk.

Kesepuluh; untuk tujuan pengajaran hakikat yang luhur; seperti ketika Nabi bertanya kepada Abu Dzar; "apakah kamu bisa melihat gunung uhud?" dijawab; "ya", Nabi bersabda; " saya tidak suka mempunyai harta seperti gunung uhud melainkan sudah aku infaqkan dalam tiga hari". Hadis ini tidak ditujukan untuk wajib dilaksanakan oleh semua umat, melainkan pengajaran hakikat yang luhur kepada umatnya.

Kesebelas; untuk tujuan al-ta'dib; seperti ungkapan Nabi ; "demi Allah tidak beriman, demi Allah tidak beriman", "sipakah dia ya Nabi ?", "yaitu orang yang tetangganya tidak bisa merasa tentram dari gangguannya". Hadis di atas tidak bisa difahami secara harfiyah, tetapi maknanya adalah tidak sempurna imannya, bukan meniadakan iman.

Keduabelas; tidak ditujukan untuk kepen- 
tingan pengajaran; bagian ini tidak ada hubungannya dengan tashri', seperti hadishadis tentang kebiasaan Nabi dalam hal pakaian, makanan, minuman, tidur, jalannya, kendaraannya dan sebagainya.

Dari paparan contoh yang telah dijelaskan oleh Ibnu 'Ashrur, kita bisa memperluas cara pandang dan sikap kita terhadap hadis -hadis Nabi yang sering kali dipaksakan untuk bisa diterapkan, disebabkan kedangkalan pengetahuan dan wawasan mufti atas hadis-hadis Nabi . ${ }^{28}$

\section{Kesimpulan}

Pada masa sahabat, adalah khalifah 'Umar Ibn al-Khattab yang sering menggunakan ketetapan hukum berdasarkan realiatas. Sebagaimana yang disebutkan dalam al-Qur'an surat al-Taubah ayat 60 tentang golongan yang mendapat hak menerima zakat, para muallaf dengan jelas dalam ayat tersebut mendapatkan jatah menerima zakat, hal ini bertujuan untuk meluluhkan hati mereka, karena pada waktu ayat tersebut diturunkan posisi Islam masih lemah. Tetapi pada saat pemerintahan dipimpin oleh 'Umar, Islam mengalami kemajuan dan dalam posisi yang kuat, sehingga 'Umar tidak lagi memberi para muallaf zakat, nama mereka dicoret oleh 'umar dari daftar penerima zakat, mengingat 'illat (reason) hukumnya sudah tidak memadai. ${ }^{29}$

\footnotetext{
${ }^{28}$ Jaseer Audah, Maqasid..., h. 234-236.

${ }^{29}$ Faisol 'Uthman, Islam dan Perkembangan Masyarakat
}

\section{DAFTAR PUSTAKA}

Yasid, Abu. 2007. Fiqh Today. Jakarta: Erlangga.

2004. Islam Akomadif; Rekonstruksi Pemahaman Islam Sebagai Agama Universal. Yogyakarta: Lkis.

al-'Amidi, 'Ali. 1404 H. Al-Ihkam fi Usuli alAhkam. Bairut: Dar al-Kitab al-'Arabi.

al-Ghazali, Abu Hamid. 1961. Maqasid al-Falsafiyyah. Cairo: Dar al-Ma'rifah.

1413 H. al-Mustashfa. Bairut: Dar al-Kutub al-'Ilmiyah.
Sebagaimana yang diungkapkan oleh $\mathrm{Abu}$ Yasid dalam pengantarnya pada buku Figh Today bahwa contoh aplikatif di atas menyisakan sebuah refleksi dan renungan buat generasi sekarang. Kalau pada kurun awal saja mediasi nalar atau akal amat berperan sentral dalam mempertautkan teks dengan konteks, apalagi pada masa sekarang, dimana bentangan historis semakin jauh antara proses kelahiran teks dengan realita social masyarakat. Dengan demikian, perlu adanya perbaikan dan evaluasi terhadap produkproduk hukum yang dianggap sudah kadaluarsa oleh para mujtahid-mujtahid dan intelektual-intelektual masa kini yang selalu dituntut untuk selalu memperluas dan memperdalam keilmuan dan wawasan akademiknya. Hal ini sesuai dengan ungkapan Nabi Agung Muhammad saw bahwa sesungguhnya Allah SWT mengutus pada setiap abad seorang pembaharu yang akan meng up-date seluk beluk urusan agamanya;

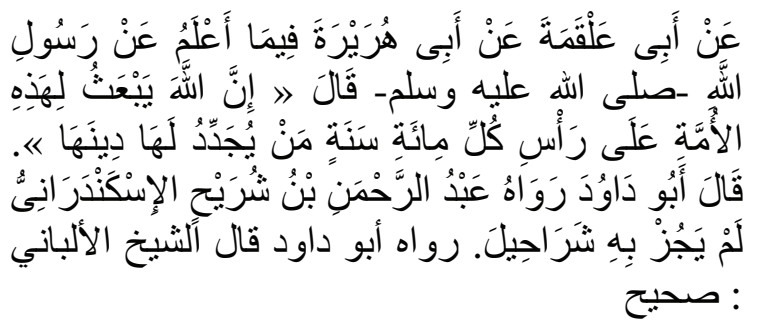

(Kuala Lumpur: Utusan Publication \& Distribution SDN BHD), h. 129.

Taymiyah, Ahmad Ibnu. 1369 H. Iqtida' alSrat al-Mustaqim Mukhalafah Ashab alJahim. Cairo: Matba'ah al-Sunnah.

Al-Bukhari. 1407 H. S\}ahih Al-Bukhary. Bairut: Dar Ibni Kathir.

al-Naysaburi, Al-Hakim. 1990. Al-Mustadrak. Dar al-Kutub al-'Ilmiyyah.

Jumaa, Ali. 1996. Usul al-Figh wa 'alaqatuhu bi al-Falsafah al-Islamiyah. Cairo: AlMa;had al-'Alami li Al-Fikr al-Islami.

Al-Suyuti. 1403 H. Ashbah wa Al-Nadhair. 
Bairut: Dar Al-Kutub al-'Ilmiyah.

Naugle, David K. 2002. Worldview; The History of Concept. Grand Rapids: Eerdmans.

'Uthman, Faisol. tt. Islam dan Perkembangan Masyarakat. Kuala Lumpur: Utusan Publication \& Distribution SDN BHD.

al-shafie, Hasan. 1998. al-'Amidiy wa Arauhu al-Kalamiyah. Kairo: Dar al-Salam.

Turabi, Hasan. 2004. Al-Tafsir Al-Tawhidi. London: Dar al-Saqi.

al-Qayyim, Ibn. tt. al-Turuq al-Hkmiyyah. Kairo: al-Madani. 1997. Ahkam Ahl al-Dhimmah. Riyadh: Ramadi.

Hajar, Ibnu. tt. Fath al-Bari. Bairut: Dar alMakrifah.

Rushd, Ibnu. 1985. Bidayah alMujtahid Wa Nihayah al-Muqtasd. Bairut: Dar Al-Fikr.

Rushd, Ibnu. tt. Bidayah alMujtahid Wa Nihayah al-Muqtasd.

Taymiyah, Ibnu. 1993. Naqd Maratib Al-Ijma'. Bairut: Dar Al-Fikr.

Al-Suyuti, Jalal Al-Din. 1993. Al-Dur Al-Manthur. Bairut: Dar Al-Fikr.
'Audah, Jaseer. 2008. Maqasid Al Shari'ah Dalil al-mubtadiin London: International Institute of Islamic Thought.

2008. Maqasid As Philoshophy Of Islamic Law. London: The International Institute Of Islamic Thought.

2007. Maqasid al-Shari'ah

Falsafah Li al-Tashrii al-Islami. London: The International Institute Of Islamic Thought.

Ibnu Musa Flousi, Masoud. 2004. Madrasah al-Mutakallimin. Riyadh: Maktabah alRush.

al-Tahir ibn 'Ashur, Muhammad. 2006. Ibnu 'Ashur Treatise on Maqasid al-Shari'ah, terj. Muhammad al-Tahir al-Musawi. London: International Institute of Islamic Thought.

Ibn 'Umar al-Razi, Muhammad. 1400 H. alMahsul, ed Taha Jabir al-Alwani. Riyadh: Imam Muhammad University Press.

De Witt, Richard. 2004. Worldviews; An Introduction to The History and Philosophy Of Sciense. Malden: MA Black Well.

a-Sajistany, Sulayman Abu Dawud. tt. Sunan Abi Dawud. Bairut: Dar al-Fikr 